\title{
PROMOTION OF ENVIRONMENTAL PROTECTION IN FILM: CASE STUDY OF DOCUMENTARY FILM “WINTER FRUITS"
}

\author{
Dejana PRNJAT \\ Academy of Arts, Serbia \\ prnjat@akademijaumentosti.edu.rs
}

\begin{abstract}
Documentary films, whether perceived as a creative treatment of actuality or as a tool for presenting life as it is, are becoming more attractive form to film artists. One of the reasons may be the fact that the documentary film is usually a smaller investment than the feature film, and that lately some of them generate quite high earnings, as the films Fahrenheit 9/11 and March of the Penguins. However, part of the charm of the documentary film is that it affects its audience differently than the feature film. Boundary line between the audience and the film almost disappears, and the audience becomes a witness. That is why the documentaries are often used for marketing purposes.

Questions related to promotion of environmental protection more and more frequently attract the attention of the documentary film makers, as evidenced by the increasing number of environmental film festivals in the world. The main aim of this paper is to present one such film - Serbian low-budget documentary film Winter fruits. Powerful message this film carries, that we should all take care of the planet Earth since it is the only place we can live on, was recognized at film festivals worldwide. The film has won numerous awards, including the very prestigious Golden Dolphin, awarded at the Documentary Film Festival in Cannes in 2011, and the Grand Prix for the best ecotourism film, awarded by CIFFT (Comité International des Festivals du film Touristique) in Vienna 2011.
\end{abstract}

Keywords: Serbian documentary film Winter Fruits, promotion of environmental protection, film festivals, awards

\section{FILMDE ÇEVRESEL KORUMA TEŞVIIKİ: ÖRNEK ÇALIŞMA "KIŞ MEYVELERI” BELGESEL FILMI}

ÖZ

İster gerçeğin yaratıcı bir tedavisi olarak isterse yaşamı olduğu gibi sunmak için bir araç olarak algılansın, belgesel filmler, film sanatçıları için daha cazip form haline geliyor. Bunun nedenlerinden biri, belgesel filmin genellikle uzun metrajlı filmlerden daha küçük bir yatırım olduğu gerçeği ve son zamanlarda Fahrenheit 9/11 ve Penguenlerin Yürüyüşü gibi bazı filmlerin oldukça yüksek kazanç getirmesi olabilir. Bununla beraber, belgesel filmlerin cazibesinin bir bölümü onun izleyicisini, uzun metrajlı filmden farklı etkilemesidir. Seyirci ile film arasındaki sınır çizgisi tamamen gözden kaybolur ve izleyici bir şahit haline gelir. $\mathrm{Bu}$, belgesellerin sıklıkla pazarlama amacı ile kullanılmasının nedenidir.

Dünyadaki çevre film festivallerinin sayısının artması ile kanıtlandığı gibi, çevre koruma teşvikine ilişkin sorular, belgesel film yapımcılarının gittikçe daha çok dikkatlerini çekiyor. Bu makalenin ana amacı düşük bütçeli Sırp Belgesel filmi olan Kış Meyvelerini tanıtmaktır. Bu filmin taşıdığı en güçlü mesaj, dünyadaki tüm film festivallerinin de farkına vardığı şey; dünyayla hepimiz ilgilenmeliyiz, çünkü o yaşayacağımız tek yer. Kış Sebzeleri, Cannes'da Belgesel Film Festivali'nde en prestijli ödül olan Altın Yunus, 2011 ödülünün yanı sıra, aynı yıl Viyana'da CIFFT (Turizm Film Festivali’nin Uluslararası 
The Turkish Online Journal of Design, Art and Communication - TOJDAC January 2016 Volume 6 Issue 1

Komisyonu) tarafından en iyi eko turizm filmi olarak verilen Büyük Ödül de dahil olmak üzere dünyadaki film festivallerinde sayısız ödül kazanmıştır.

Anahtar Kelimeler: Belgesel Film, Winter Fruits, Çevre koruma teşviki, film festivalleri, ödüller

\section{INTRODUCTION}

The term ecology is attributed to the mid $19^{\text {th }}$ century German scientist Ernst Haeckel who has, at the age of 32, in his book Generelle Morphologie der Organismen ${ }^{1}$ coined a new word from two words of Greek origin - oikos (hous) and logos (science). This term represented the science researching the relationship between the organisms and their environment, ${ }^{2}$ and "leading idea of the ecology today became the idea of sustainable or ecologically balanced development, society development which would consider limitation of many natural resources and the need to consider the nature and its parameters as primary framework, and often the main goal of the development".

Most people have too long been acting as if they are not part of nature and that they do not depend on it, which led to the fact that the life of future generations on this planet will be very difficult, if not impossible. In this regard, the ecology cannot be of concern only to people who pursue it as their profession, because the resources such as air and water are necessary for life of all beings.

Among people who do not deal with this issue professionally, but feel the need to point out the problem, are undoubtedly the filmmakers. They contribute by making films that deal with ecology as a theme, promoting the issue of environmental protection, and quite often they are able to achieve significant results on minimal resources. Therefore the main aim of this paper is to present one such a film, which had a budget of just 2,500 Euro but went on to win a large number of awards at international festivals, including the prestigious award for best ecological film at the international festival of Cannes Corporate Media@ TV Awards 2011. It is the most successful Serbian ecological film, "Winter Fruits".

The main empirical research methods used in the paper are case study and content analysis.

\section{FILM AND ECOLOGY}

The first films were at the same time the first documentaries, as they recorded things as they actually were. Most often quoted as the first film is the short black and white silent film Workers Leaving the Lumiere Factory in Lyon from 1895 directed and produced by Louis Jean Lumiere, although also preserved is the film lasting about two seconds, but dating from seven years earlier, entitled Roundhay Garden Scene directed by Louis Aime Augustin Le Prince. ${ }^{4}$ The first documentaries filmed in Serbia were done in March of 1897. "During his second stay in Belgrade, Andre Carr shot his first frames in Serbia - the "Kalemegdan Promenade", the "Tramway Station at Terazije" and "Workers Coming out of the Tobacco Factory". 5

When watching a feature film, the audience is always aware that it is the artistic interpretation of an event, even if the film was based on a true story, while the documentary creates an altogether different rapport with the audience. It puts them in the role of a witness. It is also given a credibility which may not always belong to it, since the audience often forgets that the choice and sequence of frames they are watching,

\footnotetext{
${ }^{1}$ Ernst Haeckel 1866 Generelle Morphologie der Organismen, Berlin:Druck und Verlag von Georg Reimer

${ }^{2}$ Ecology Revisited: Reflecting on Concepts, Advancing Science (A. Schwarz and K. Jax, ed.), 2011. Springer, p. 146

${ }^{3}$ Vukasin Pavlovic, 1997. "Religija i ekoloska kriza”, Kultura br. 95, Beograd: Zavod za proucavanje kulturnog razvitka, p. 19

${ }^{4} \mathrm{http}: / /$ www.imdb.com/title/tt0392728/ (12.01.2014.)

5 Dejan Kosanovic, "Serbian Film and Cinematography" (1896-1993) http://www.rastko.rs/isk/dkosanoviccinematography.html (04.04.2013.)
} 
The Turkish Online Journal of Design, Art and Communication - TOJDAC January 2016 Volume 6 Issue 1

music and sounds which accompany the image are also interpretation of an event, as well as that the author of the documentary approaches a certain problem with an idea to send a message. "Documentary cinematography is infinitely interesting for the creators of art cinematography due to the fact that it sharpens the view and teaches observing, teaches the art of expression, teaches the correct and upstanding human behavior, the situation on the screen without which it would be impossible for a work of art to be interesting or convincing."

Much less money is usually invested into documentaries than into feature films, and the earnings are also significantly smaller. However, films like Fahrenheit 9/11, which earned about 120 million dollars ${ }^{7}$ in the US only, or La Marche de l'empereur (March of the penguins), which earned 78 million dollars, ${ }^{8}$ at the box-offices in the US are pointing to the change. Perhaps the financial success of Michael Moore's film, winner of many awards, among which is the Palme d'Or in Cannes $2004,{ }^{9}$ is not surprising, as it speaks about the attack on the World Trade Center in New York on 11 September 2001, however, success of a French documentary, winner of the Academy Award for the best documentary $2006^{10}$, portraying annual journey of the Emperor penguins and their care for their offspring may be considered as a surprise. One of the possible explanations for this much interest in Luc Jacquet's film can be found in the fact that humans, who have for the longest time only been interested in the exploitation of the natural resources, including their own kind, faced now with obvious and for a good part unrepairable imbalance in nature slowly regain the awareness of its importance.

This is supported by the increasing number of film festivals in the world dealing with the environment. Today there are more such festivals in Serbia as well. Among the most famous are the International green culture festival Green Fest in Belgrade, the International Festival of Tourism and Environmental Film Festival Silver Lake Tourfilm Festival - SILAFEST in Veliko Gradiste, International Festival of Ecological and Archaeological Film EKOPOLIS in Nis, Eco Dox festival of environmental documentaries as part of European Film Festival Palic, etc.

Although increase in number of film festivals specializing in ecology films indicates that the awareness on the relevance of this subject is growing, we should not forget the economic side of the festival. "The festivals contribute to income earning in several ways. Vaughan indicates three such ways: direct income is derived from earnings, rents and profits paid to the locals on the basis of tourists" spending, hotel earnings and store earnings. Indirect income are the earnings, rents and profits of those who supply the hotels, stores, and other services which deal with the tourists directly. Also, there is the induced income derived from the costs of earnings of those who received wages, profit, or rents on the basis of doing business with the tourists - festival visitors". ${ }^{11}$

\footnotetext{
${ }^{6}$ Oleksandar Dovzenko, “On Documentary Film” http://www.rastko.rs/rastko-ukr/umetnost/odovzenkodokumentarni.html (04.04.2013.)

${ }^{7} \mathrm{http}: / / \mathrm{www}$. boxofficemojo.com/movies/?id=fahrenheit911.htm ( 14.01.2014.)

${ }^{8} \mathrm{http}: / / \mathrm{www}$. boxofficemojo.com/movies/?id=marchofthepenguins.htm ( 14.01.2014.)

${ }^{9} \mathrm{http}: / / \mathrm{www} . \mathrm{imdb} . \mathrm{com} / \mathrm{title} / \mathrm{tt} 0361596 /$ awards?ref_=tt_awd (12.01.2014.)

${ }^{10} \mathrm{http}: / / \mathrm{www} . \mathrm{imdb} . \mathrm{com} / \mathrm{title} / \mathrm{tt0428803/awards?ref}=\mathrm{tt}$ awd (12.01.2014.)

${ }^{11}$ Roger Vaughan, 1976. The Economic Impact of Edinburghs Festival, Edinburgh, 1976. Scottic11 Tourist Board, cit. in: Branimir Stojkovic, 1994. "Pozorišni festival i društveno okruženje, analiza komunikacinog procesa", Kultura br 93/94 Zavod za proucavanje kulturnog razvitka, Beograd, p.81
} 
The Turkish Online Journal of Design, Art and Communication - TOJDAC January 2016 Volume 6 Issue 1

Milos Nemanjic observed the economic function of the award from the point of view of the winner, and emphasizes that it can be direct, which is the amount of money awarded to the winner, or indirect, which is realized through the popularity of the piece and author being awarded and implies earnings from all future and previous works, at higher prices. ${ }^{12}$

Probably the most important author of the nature and nature conservation documentaries in Serbia is Petar Lalovic, and the most famous films that the cinema audiences were able to watch are The Last Oasis and The Disappearing World. Lately the increasing number of Serbian authors have received important acknowledgements worldwide making ecology films, among others Miodrag Miki Andric, whose film Divine River presenting Danube won Grand Prix on jubilee $50^{\text {th }}$ festival of the tourist film in Lecce, Italy in the area of eco-tourism in $2012^{13}$, Nebojša Ilic Ilke with films Dream of an Ancient Dreamer, Moby Dick - floating country, Road to the Mountain, which won more than 20 awards on European festivals of documentary and ecology films, ${ }^{14}$ and especially Bosko Savkovic whose film Winter Fruits won many awards worldwide, including the most famous ones, as is the Golden Dolphin in Cannes 2011 and the award for the best ecology film in the world that same year. One year later Savkovic also won Silver Dolphin in Cannes for the film After bombs. "In contemporary artistic creating, an award appears in function of affirmation/mark via which the work is placed within the area of art creativity (and outside banality and dilettantism) not only because the author believes it such, but also based on the opinion of those (award jury members) who legitimately represent cultural public"15

\section{FILM "WINTER FRUITS"}

Awards are the key part of every festival. "The need for value selection of works of art has always existed, although the criteria vary from time to time, from country to country. Each evaluation involves the existence of pre-determined criteria, and usually is not a matter of individual taste." ${ }^{16}$ During the award ceremony, the jury has a responsible role because "their voice "for" or "against" rewarding work, does not determine only the fate of the work, but also the fate of its author, and forms the taste of the audience". ${ }^{17}$

The only Serbian documentary which received Golden Dolphin award for the best ecology film on the prestigious international film festival Cannes Corporate Media \& TV Awards is the film Winter fruits by director Bosko Savkovic. The award was received in 2011, and as reported by International festival of tourist and ecology films SILAFEST, this film is, "apart from the films by Emir Kusturica, the only Serbian film that has ever won in Cannes, in both categories - feature and documentary film"18

Film was supported by City secretariat for environmental protection of Belgrade with 2500 euros, and its Chairwoman Natasa Djokic, said on winning the Cannes award: "City secretariat for environmental protection supported the making of this film because we recognized its educational value. "Winter fruits" is the film with message which is universal and understandable to everybody, and that is - we should take care of our environment" 19

\footnotetext{
${ }^{12}$ Milos Nemanjic, 1981. "Knjizevne nagrade - drustvena i umetnicka funkcija”, Kultura-dokumentacija, sv. br.1, Zavod za proučavanje kulturnog razvitka SR Srbije, Beograd, pp.7-8

${ }^{13} \mathrm{http}$ ://www.novosti.rs/vesti/kultura.71.html:386677-Italija-Gran-pri-nasem-dokumentarcu (07.04.2014.)

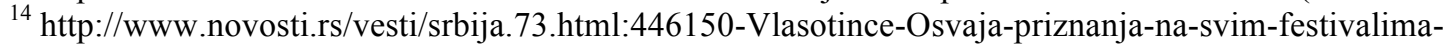
dokumentaraca (22.04.2014.)

${ }^{15}$ Branimir Stojkovic (1994) „Pozorisni festival i drustveno okruzenje“, Kultura 93/94, Beograd: Zavod za proucavanje kulturnog razvitka, p. 74

${ }^{16}$ Dejana Prnjat (2013) Kulturna politika, Akademija umetnosti, Beograd, pp. 29-30

${ }^{17}$ Jovanka D. Božić (1995) Umetnost u svetlu nagrade, Javno kulturno-informativno preduzeće "Ub", Ub, p. 80

${ }^{18} \mathrm{http}: / / w w w . b l i c . r s / k u l t u r a / v e s t i / s r p s k o m-e k o l o s k o m-d o k u m e n t a r c u-n a g r a d a-u-k a n u / s 8 d j b z q ~(13.06 .2014$.

${ }^{19} \mathrm{http}: / /$ www.beograd.rs/cms/view.php?id=1476759 (04.06.2014.)
} 
Apart from this, the film won four other awards in 2010 and nine in 2011, a total of 14 awards: ${ }^{20}$

1. Grand Prix CIFFT - Special award for the best ecotourist film in the world in 2011., Festival of all festivals festivala - Grand Prix CIFFT 2011, Vienna, Austria 2011.

2. Golden Kitovras for the best ecological film of the festival on the International festival of tourist and cultural film "Kitovras", Veliki Novgorod, Russia 2011.

3. Golden Rooster for the best ecological film of the festival on the International festival of tourist film "ART \& TOUR" - Barcelos, Portugal 2011

4. Special award of the festival International festival of the art and tourist film "FilmAT" - Warsaw, Poland 2011

5. Golden Arara for the best ecological film on the International festival "Tourfilm Brazil" Florianopolis, Brazil 2011

6. Jury award on the International festival of tourist film in Riga "Tourfilm Riga" - Riga, Letonia 2011

7. Special commendation on the International festival of tourist film in Riga "Tourfilm Riga" Riga, Letonija 2011

8. The best ecological film of the festival „Film in bottle “ - belgrade, Srbija 2011

9. Award in category best ecology film of the festival „Dokumentart“ - Campulng, Romania 2011

10. Golden Pincum for the Best Serbian ecology film, International festival of tourist and ecology film "SILAFEST" - Veliko Gradište, Srbija 2010

11. Special award, $4^{\text {th }}$ International festival of tourist and ecology film „Jahorinafest“ - Pale, Bosnia and Herzegovina 2010

12. Best ecology film, International festival „Golden Peak “- St. Petersburg, Russia 2010

13. Special award for the best film from Nevsky Institute for language and culture, International festival „Golden Peak “ - St. Petersburg, Russia 2010

The awarded film lasts five and a half minutes and was made in two versions - Serbian and English. Practically no words are spoken, and interestingly enough, the scenes from the Belgrade market at the beginning of the film are accompanied by murmur in English in both versions of the film. The only language message is found at the end of the film "These winter fruits can reach your backyard too, wind does not recognize boundaries, that we, people, put. It takes thousands of years for nature to degrade these winter fruits. Think about it when you use plastic bags. Save the planet. We do not have other place to live on!"21

Film shows plastic bags everywhere - on the streets, grass areas, in the tree tops, in the rivers. The film's author, Bosko Savkovic, explains his reasons behind making of this film: "When I was a teenager, a plastic bag was a status symbol. We used to carry our trainers and technical drawing kit in the plastic bags which we would get from abroad, or at the duty -free shops... Manufacture is now cheap, so every vendor has access to them - the ones on the streets, on the markets, in supermarkets... As they are thin and light they fly up easily. The tragic thing is that the half-life of the materials in bags lasts thousands of years" 22

Young Canadian Daniel Burd, however, managed to largely resolve this problem. "It's not your average science fair when the 16-year-old winner manages to solve a global waste crisis. But such was the case at last May's Canada-Wide Science Fair in Ottawa, Ontario, where Daniel Burd, a high school student at Waterloo Collegiate Institute, presented his research on microorganisms that can rapidly biodegrade

\footnotetext{
${ }^{20} \mathrm{http}: / /$ alternib.com/srpski/html/nagrade_priz.html (08.06.2014.)

${ }^{21} \mathrm{https}: / /$ www.youtube.com/watch? $\mathrm{v}=8 \mathrm{uDLVHJ} 5 \mathrm{zu} 4(10.11 .2011$.

$22 \mathrm{http}$ ://www.vesti-online.com/Stampano-izdanje/06-11-2011/Intervju/177127/Pare-za-film--samorodbini/print(07.06.2014.)
} 
The Turkish Online Journal of Design, Art and Communication - TOJDAC January 2016 Volume 6 Issue 1

plastic." ${ }^{23}$ According to his research "every year, approximately 500 billion plastic bags are used worldwide and billions of those are dumped into the oceans. Countless wildlife, including sea-lions, whales, birds and turtles ingest the plastic bags and die every year. Plastic bags have very high durability, persisting in the environment for 20 to 1000 years before they decompose" 24

In the proceedings of joining the European Union, Serbia has also adopted a group of laws which relate to the waste management, but it has neither the money nor the technical resources to apply these laws. ${ }^{25}$

\section{CONCLUSION}

Considering that Bosko Savkovic's agency "'Alternativa' is the executive producer and organizer of the International Festival of Tourism and Ecology Film - SILAFEST, which takes place in Veliko Gradiste every year at the end of August, ${ }^{, 26}$ it is possible to assume that some of the awards were received from collegial reasons. It is well known that "not only the quality, value of the work or the entire body of work are factors here, but there are others... There can be various attempts to influence the work of the jury - by the candidates themselves, by interested parties or institutions (publishers, producers, galleries...) or by some jury members who could be connected to the candidates or their supporters via various business and personal relationships. In the situation where both jury members and the candidates belong to the same cultural environment, the probability of positive or negative judgement which is not based solely on the merits of the item judged, is certainly quite high". ${ }^{27}$

On the other hand, it would definitely be more than unfair to attribute all the awards to such circumstances, since this film is sending out a very current and at the same time universal message about the need to take care of the planet Earth, because, at least for now, we do not have another one we could live on. It also emphasizes the importance of each person's behavior towards his or her environment because it affects both him or her and the future generations. Although created on a shoestring budget, this film won very important awards, because of this message it is sending out.

Even though the films dealing with environmental protection are most often not noticed by the wider audiences, and quite often not even available to them, there is no doubt that the films with this thematic are going to become more and more significant in the times to come.

\section{REFERENCES}

Bozic, J. 1995. Umetnost u svetlu nagrade, Javno kulturno-informativno preduzeće "Ub", Ub

Ecology Revisited: Reflecting on Concepts, Advancing Science (A. Schwarz and K. Jax, eds.), 2011. Springer

Haeckel, E. 1866. Generelle Morphologie der Organismen, Berlin:Druck und Verlag von Georg Reimer Nemanjic, M. 1981. "Književne nagrade - društvena i umetnička funkcija", Kultura-dokumentacija, sv. br.1, Zavod za proučavanje kulturnog razvitka SR Srbije, Beograd

Pavlovic, V. 1997. "Religija i ekoloska kriza", Kultura br. 95, Zavod za proucavanje kulturnog razvitka, Beograd

Prnjat, D. 2013. Kulturna politika, Akademija umetnosti, Beograd

Stojkovic, B. 1986. „Kulturni heroj i pobednicko slavlje“, Kultura br. 73/74/75, Zavod za proučavanje kulturnog razvitka, Beograd

\footnotetext{
${ }^{23} \mathrm{http}$ //www.mnn.com/green-tech/research-innovations/blogs/boy-discovers-microbe-that-eats-plastic(07.06.2014.)

${ }^{24} \mathrm{http}: / /$ wwsef.uwaterloo.ca/archives/2008/08BurdReport.pdf (05.09.2014.)

${ }^{25} \mathrm{http}: / /$ serbia-energy.eu/sr/2011/11/zatita-ivotne-sredine-uslov-za-eu/ (08.12.2013)

${ }^{26} \mathrm{http}: / /$ alternib.com/english/html/about_us.html (07.04.2014.)

${ }^{27}$ Branimir Stojković,1986. „Kulturni heroj i pobedničko slavlje“, Kultura br. 73/74/75, Zavod za proučavanje kulturnog razvitka, Beograd, p. 310
} 
The Turkish Online Journal of Design, Art and Communication - TOJDAC January 2016 Volume 6 Issue 1

Stojkovic, B. 1994. Pozorišni festival i društveno okruženje,analiza komunikacinog procesa, Kultura br. 93/94 Zavod za proucavanje kulturnog razvitka, Beograd

Vaughan. R. 1976. The Economic Impact of Edinburghs Festival, Edinburgh, Scottic11 Tourist Board

http://alternib.com/

http://serbia-energy.eu/

http://www.imdb.com/

http://www.boxofficemojo.com/

http://www.novosti.rs/

http://www.blic.rs/

http://www.beograd.rs/

https://www.youtube.com/

http://www.vesti-online.com/

http://wwsef.uwaterloo.ca/

http://www.rastko.rs/isk/dkosanovic-cinematography.html 